\title{
核燃料の耐食性と表面処理
}

緒 方 恵 造*

\section{Corrosion Resistance and Surface Treatment of Nuclear Fuel Elements}

Keizo OGATA*

Key Words : Nuclear Fuel, Corrosion, Zirconium Alloy, Surface Treatment

原子炉で使用されるジルコニウム合金は高温冷却水に より腐食される。腐食挙動には水質や放射線が大きく影 響し，材料面では合金成分の寄与が大きく表面処理の効 果は比較的小さい。現状では腐食量は問題ではないか, 一層の性能向上を目指して熱処理や合金成分調整等によ る耐食性改善研究が進められている。

\section{1. まえがき}

日本に打ける原子力発電は総電力需要の約 $30 \%$ 占め るに至っており, 重要なエネルギー源の一つとなってい る。原子炉は中性子と核分裂性核種の核反応を利用する あので, 中性子のエネルギーあるいは冷却材の違い等に よって種々の炉型がある。世界的に商業用発電の主流と なっているのは軽水炉と呼ばれ，核燃料から除熱する冷 却材として軽水 (重水 ${ }^{2} \mathrm{H}_{2} \mathrm{O}$ と区別して通常の水を軽水 と呼ぶ）を用いるあのである。

軽水炉に抢ける核燃料は放射線照射下で $300^{\circ} \mathrm{C}$ 近傍の 高温水中で使用され，3〜4年 (場合によってはそれ以上) の寿命中に破損の無い上う高い信頼性が要求される。国 産燃料の高度の信頼性は, 商用発電炬で使用された燃料 の詳細な試験・検査 (照射後試験)によって実証されてお $り^{11,2)}$, 腐食の点でも問題の無いことが確認されている。

一方, 原子力発電の経済性向上および資源の有効利用 という点から, 核燃料の使用期間を長期化して, 取り出 すエネルギー量を増加させる高燃焼度化 (燃焼度 : 単位 燃料重量あたりの積算熱出力）が進められつつあり ${ }^{3)}$, 高温水による燃料棒外面の腐食が重要な検討項目の一つ として指摘されている ${ }^{3), 4)}$ 。現在の燃料使用条件下では, 外面腐食は燃料の寿命制限因子とはなっていないが(1),2), 使用期間の長期化により腐食量の増加が予測され，その 低減に向けての研究開発が進められている。

\section{*日本核燃料開発(侏)（开311-13 茨城県東茨城郡大洗町成田町} 2163)

Nippon Nuclear Fuel Development Co.,Ltd. (2163, Oaraimachi Narita-cho, Higashi-Ibaraki-gun, Ibaraki 311-13)
本報では軽水炉における燃料棒の外面腐食に関する現 状と耐食性改善の動向について概説した。

\section{2. 核燃料の概要}

軽水炉には沸騰水型 (BWR) と加圧水型 $(\mathrm{PWR})$ の 2 つの型がある。BWRでは約 $70 \mathrm{~kg} / \mathrm{cm}^{2}$ に加圧された 冷却水が炉心部で体沸騰し, 発生した蒸気が直接夕ービ ンに送られる。PWRでは冷却水は体沸騰を抑制するた めに約 $157 \mathrm{~kg} / \mathrm{cm}^{2}$ に加圧されており, 二次冷却系の蒸 気発生器で熱伝達する。冷却材の水質 ${ }^{5)}$ は, PWRでは $\mathrm{pH}$ 調整用の $\mathrm{LiOH}$ や核反応度制御用の $\mathrm{H}_{3} \mathrm{BO}_{4}$ が添加さ れ, さらに溶存酸素低減のための水素添加が実施されて いる。BWRでは沸騰により添加物が濃縮されるため薬 液, 水素の注入は行わず, 中性の水が用いられている。 冷却材水質の例 ${ }^{5)}$ を表 1 および表 2 に示す。

軽水炉で使用される燃料は, $\mathrm{UO}_{2}$ 粉末を成型燒結し たペレットを直径約 $10 \mathrm{~mm}$, 肉厚 $0.6 \sim 0.9 \mathrm{~mm}$ (燃料設 計によって異なる）の燃料被覆管に装てんしたもの（燃 料棒) で, これを多数本束ねた燃料集合体として原子炉 の炉心に装荷する。燃料集合体の構造の一例を図 1 に示 す。

燃料集合体の構造部材は, 強度・延性等の機械的性質 および耐食性に優れたすのである他，核分裂により発生 した中性子を次の核分裂に有効に利用できるよう中性子 吸収の小さなものでなければならない。中性子吸収の程 度は各元素に固有のあので, 材料はおのずと限られてく る。この観点から軽水炉ではジルコニゥム $(\mathrm{Zr} r)$ に微 量の他元素を添加した合金ジルカロイが使われている。

ジルカロイはZrの耐食性を向上させることを主目的 に開発されたもので6), 微量の $\mathrm{Sn}, \mathrm{Fe}, \mathrm{Cr}, \mathrm{Ni}$ 加え たジルカロイー 2 と, 水素吸収を低減するためにこれか ら $\mathrm{Ni}$ 除き $\mathrm{Fe}$ を増したジルカロイー 4 とがある。これ らの化学成分を表 3 に示す。耐食性の点では両者同等と 言われているが, BWRでは燃料被覆管にジルカロイー 2 , スペーサ（燃料棒間の間隔保持のための支持格子） 
表 1 BWR冷却水水質の概略 ${ }^{5)}$

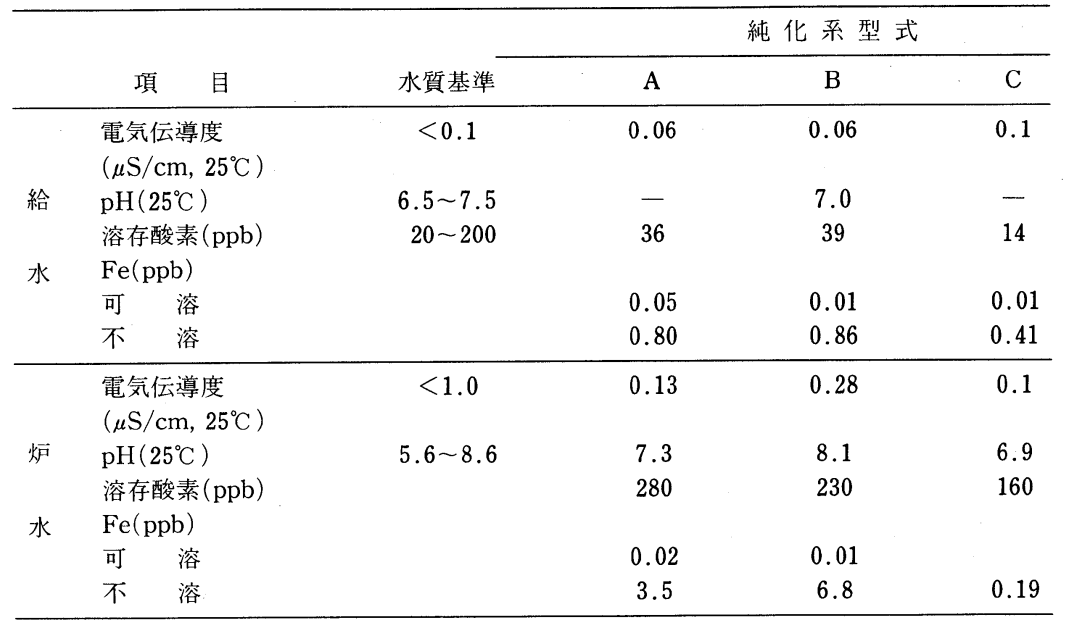

表 2 PWR冷却水水質の概略 ${ }^{5)}$

\begin{tabular}{|c|c|c|c|}
\hline 項 目 & 標準值 & 限度值 & 測定值 \\
\hline ほう素(ppm) & $0 \sim 4000$ & - & \\
\hline リチウム $(\mathrm{ppm})$ & $0.2 \sim 2.2$ & 2.2 & \\
\hline 水 素(cc-STP $/ \mathrm{kg})$ & $25 \sim 35$ & $15 \sim 50$ & $\sim 30$ \\
\hline $\mathrm{pH}\left(25^{\circ} \mathrm{C}\right)$ & $4.2 \sim 10.5$ & - & $6 \sim 7.5$ \\
\hline 電気伝導度 $\left(\mu \mathrm{S} / \mathrm{cm}, 25^{\circ} \mathrm{C}\right)$ & $1 \sim 40$ & - & \\
\hline 酸＼cjkstart素(ppm) & $<0.005$ & $<0.1$ & $<0.005$ \\
\hline 塩 素(ppm) & $<0.05$ & $<0.15$ & $<0.05$ \\
\hline 了。素( & $<0.05$ & $<0.15$ & $<0.05$ \\
\hline 鉄 $\quad(\mathrm{ppm})$ & $<0.05$ & & $<0.01$ \\
\hline けい素( $(\mathrm{ppm})$ & $<0.5$ & & $\sim 0.3$ \\
\hline
\end{tabular}

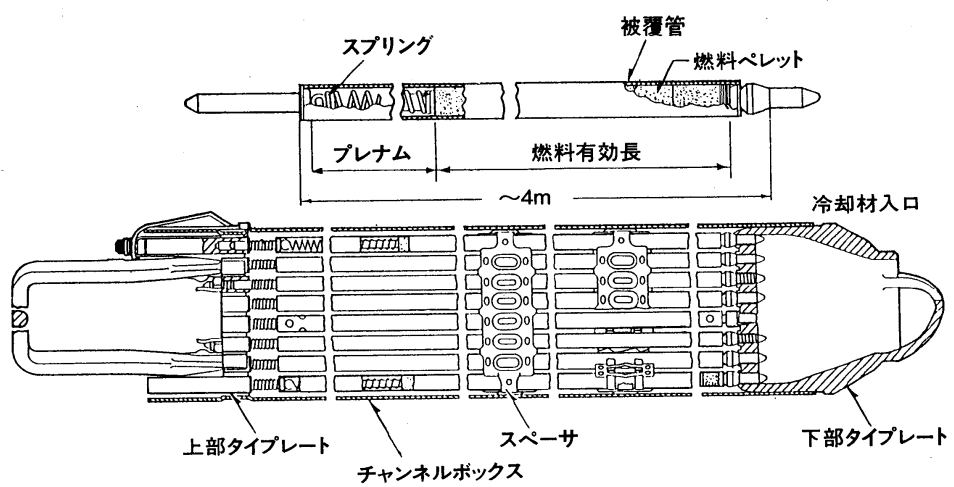

図 1 BWR燃料集合体の構造例

表 3 ジルカロイの合金組成

(JIS H4751-1981)

\begin{tabular}{ccc}
\hline 合金成分 & ジルカロイ -2 & ジルカロイ 4 \\
\hline $\mathrm{Sn}$ & $1.20 \sim 1.70$ & $1.20 \sim 1.70$ \\
$\mathrm{Fe}$ & $0.07 \sim 0.20$ & $0.18 \sim 0.24$ \\
$\mathrm{Cr}$ & $0.05 \sim 0.15$ & $0.07 \sim 0.13$ \\
$\mathrm{Ni}$ & $0.03 \sim 0.08$ & - \\
\hline $\mathrm{Fe}+\mathrm{Cr}+\mathrm{Ni}$ & $0.18 \sim 0.38$ & $0.28 \sim 0.37$ \\
\hline
\end{tabular}

等にジルカロイ -4 が使用され, PWRではジルカロイー 4 が使用されている。

\section{3. 燃料棒の外面腐食}

\section{1 ジルカロイの腐食挙動}

燃料棒の外面腐食は，冷却水之接する被覆管すなわち ジルカロイの高温水による次の酸化反応である。

$$
\mathrm{Zr}+2 \mathrm{H}_{2} \mathrm{O} \longrightarrow \mathrm{ZrO}_{2}+2 \mathrm{H}_{2}
$$

腐食に伴って被覆管表面には酸化皮膜が形成されると とあに発生した水素の一部は金属中に侵入する。ジルカ ロイ中で固溶限 $\left(300^{\circ} \mathrm{C}\right.$ で約 $\left.70 \mathrm{ppm}\right)$ を超えた水素は $\mathrm{ZrH}_{1.5}{ }^{7)}$ として析出し，その量が増加すると被覆管の ぜい化が問題となる。このため, 材料の腐食による減肉 


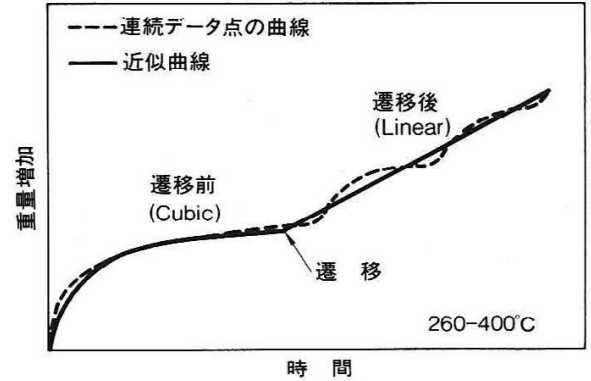

図 2 ジルカロイー 2 およびー 4 の 260 ～ $400^{\circ} \mathrm{C}$ における腐食挙 動 ${ }^{\text {9) }}$

とともに付随する水素吸収す考慮しておく必要があるが, これまでのところ，これに起因する不具合は生じていな (1),2)

炉外試験（原子炉内の放射線照射環境下における炉内 （照射）試験に対して実験室等での非照射下の試験を炉 外試験として区別する）におけるジルカロイの腐食につ いては, 高温水または水蒸気中腐食試験によって調べら れており ${ }^{8), 9)}$, 図 2 に示すように遷移点を境に腐食速度 が変化する。遷移前では保護性の酸化皮膜が形成され, 腐食量は時間の $1 / 3$ 乗に比例して増加する（3 乗則）が, 遷移後は時間に比例する（直線則）。遷移前では保護性 の酸化膜を通した酸素イオンの内方拡散が腐食を律速し ていると考えられており，酸化膜の保護性喪失により遷

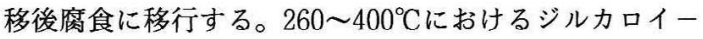
2 と 4 に共通の腐食速度式として, 腐食量を酸化による 重量増加 $\Delta W\left(\mathrm{mg} / \mathrm{dm}^{2}\right)$ で示した次式がある ${ }^{9)}$ 。

遷移前 $\Delta W^{3}=6.36 \times 10^{11} \exp (-13636 / T) t$

遷移後 $\Delta W=1.12 \times 10^{8} \exp (-12529 / T)\left(t-t_{\mathrm{t}}\right)$ $+\Delta W_{\mathrm{t}}$

$\Delta W_{\mathrm{t}}=75.3 \exp (-553.6 / T)$

ここで, $t$ : 時間 (day), $T$ : 温度 $(K)$ であり, 添字 $\mathrm{t}$ は遷移点を示す。なお, 後述するノジュラ一腐食につ いては, 炬外試験条件下ではこのような温度では発生せ ず, 約 $500^{\circ} \mathrm{C}, 100 \mathrm{~kg} / \mathrm{cm}^{2}$ 程度の高温高厈水蒸気中で 24 時間程度の短時間腐食試験で発生する ${ }^{(0)}$ 。

原子炉内で使用された被覆管の腐食には 2 種類の形態 がある9 。一つはPWRで主に観察される一様な厚さに 成長した均一腐食で, 上述の $400^{\circ} \mathrm{C}$ 程度以下の炉外腐食 試験と同様の腐食形態である。もう一つはノジュラー腐

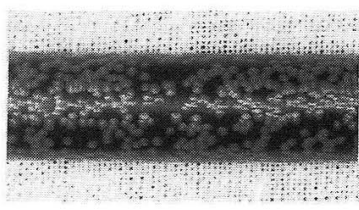

図 3
食と呼ばれ，BWRで使用されたジルカロイー2 と 4 い ずれにも観察される。,ジュラ一腐食は比較的薄い均一 酸化膜で覆われた表面に死白色の斑点状腐食として観察 されそその断面はレンズ状をしている。ノジュラ一腐食 の例を図 3 に示す。ノジュラ一腐食の発生原因は十分に 解明されるには至っていないが, ジルカロイ中に析出物 として，あるいは微量に固溶して存在する合金成分の分 布状態が大きく影響しているあのと考えられる ${ }^{11), 12) 。 ~}$ この他にも被覆管の製造履歴あるいは後述の水質等が影 響因子として指摘されている。

PWRとBWRの腐食形態の違いは水質の影響と考え られる。PWRでは水素添加により冷却水中の酸素を抑 えているが，BWRでは水の放射線分解により生成する 酸素のため溶存酸素濃度は約 $200 \mathrm{ppb}$ 上見積られている。 PWRでも溶存酸素濃度が高い状態で運転された場合に はノジュラー腐食が発生した例 ${ }^{13)}$ があり，冷却水中の溶 存酸素がノジュラー腐食発生に寄与しているむのと考え られる。

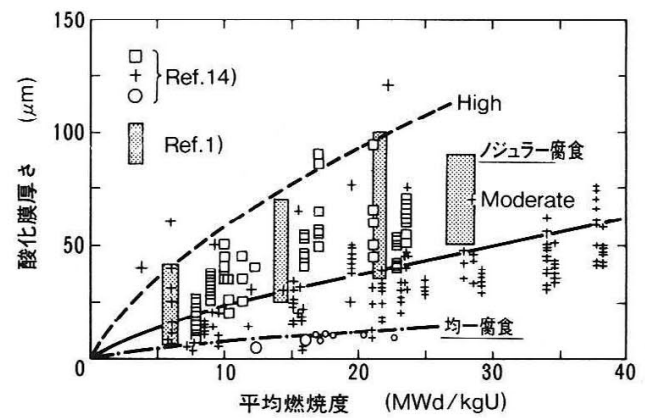

図 4 BWR中で生じたノジュラー腐食厚さと燃焼度の関係

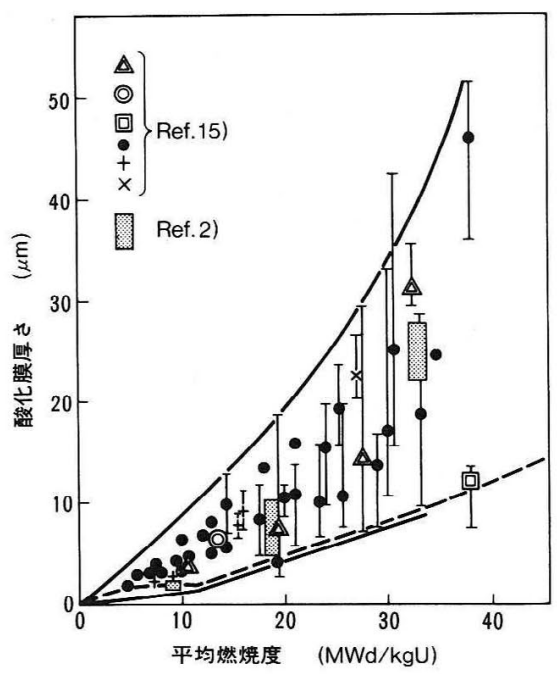

図 5 PWR中で生じた均一腐食厚さと燃焼度の関係 
燃料棒の外面腐食厚さは一般に, 使用期間と熱出力の 積に相当する尺度である燃焼度との関係で整理されてい る。BWRにおけるノジュラ一腐食の最大厚さと燃焼度 の関係を図 $4^{1{ }^{1)} \text {,14) }}$ に，PWRにおける均一腐食のそれを 図 $5^{2), 15)}$ にそれぞれ示す。いずれにあ大きなばらつきが 見られ，上限に近い場合には高燃焼度化した場合に問題 となるが，下限に近い場合には余裕がある。このような ばらつきの原因は十分には解明されておらず，冷却材水 質および材料特性の両面から種々検討されている ${ }^{12)}$ 。ま た，PWRとBWRとで腐食厚さの増加傾向に違いが見 られ，PWRでは直線的に増加しているのに対しBWR では徐々に飽和する傾向がある。これは後述の照射加速 効果および熱流束の影響の違いによるものと考えられる。

PWRとBWRについて炉内腐食速度と温度との関係 を炉外試験のそれと比較して模式的に示した例 ${ }^{15)}$ を図 6 に示す。炬内照射下では腐食速度は炉外試験と比べて大 きく，いわゆる照射加速効果 ${ }^{16)}$ が生じる。照射加速効果 の原因には水の放射線分解之, 中性子による材料および 酸化膜の損傷が考えられており，水素添加によって酸素 を抑えているPWRの方がBWRより小さい傾向にある。 また，BWR中での腐食はあまり温度依存性がないが, これは温度より放射線分解の影響を強く受けるためと考 えられる。この他, 燃料棒では内部の燃料ペレットの発 熱を外側で冷却除熱しており，被覆管は熱流束下で使用 される。腐食が進行すると, 酸化膜の低い熱伝導度のた めに酸化膜と金属の界面温度が上昇し，腐食速度が増加 する可能性がある。この効果は図 6 に模式的に示されて いるが, 均一腐食形態で, かつ腐食速度の温度依存性が 強いPWRでより大きいと考えられる。

燃料棒の腐食厚さの軸方向分布の例 ${ }^{15)}$ を図 7 に示す。

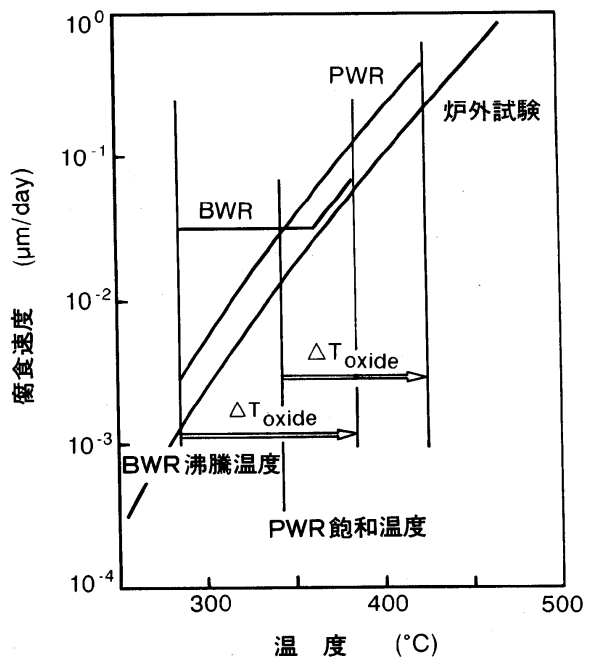

图 6 PWRおよびBWR中でのジルカロイ被覆管の腐食挙動 ${ }^{15)}$

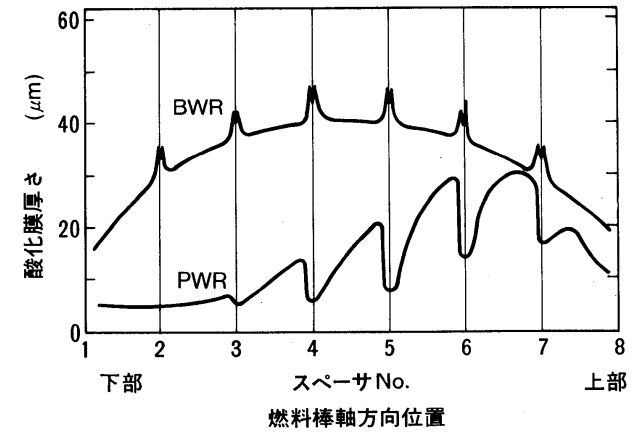

図 7 PWRおよびBWR燃料棒の酸化膜厚さ軸方向分布の例 ${ }^{15)}$

PWRの場合は下端（冷却材入口）から上方に温度が上 昇するため, 腐食厚さの分布は温度分布と対応している。 スペーサ部では除熱が良くなるために腐食の低下が見ら れる。BWRでは冷却水は沸騰するため軸方向温度分布 は小さく, 照射加速効果により腐食厚さの分布は出力す なわち中性子束や $\gamma$ 線束の分布の影響を受けている。ス ペーサ部では腐食の増加が見られるが，これはスペーサ のバネ材として使用されているインコネルとの接触によ る電気化学的効果と考えられる

\section{2 被覆管の表面処理}

ジルカロイ被覆管は, 真空溶解したインゴットを鐉造, 溶体化処理, 熱間押出しにより素管に形成し, その後冷 間圧延と焼鈍を繰り返して最終寸法に加工される。ジル カロイの腐食においては, 表面傷あるいは粗い表面で局 部的に腐食が増加したりノジュラー腐食が選択的に発生 する傾向がある ${ }^{8)}$ 。このため, 最終焼鈍後の被覆管外面 は機械研磨により平滑に仕上げられ，さらにフッ化水素 酸之硝酸の混合水溶液中で化学研磨, あるいは電化研磨 で仕上げる場合もある。また，これらに加えて約 $400^{\circ} \mathrm{C}$ の水蒸気中で厚さ $1 \mu \mathrm{m}$ 以下の薄い酸化膜を形成する (オートクレーブ処理) 場合あある。この処理は, 表面 が正常な場合には光沢のある黒色酸化膜となるが，異物 の付着や局所的な金属成分の異常がある場合には光沢の ある黒色を呈さないことから, 被覆管表面の検査手段と しても用いられたが, 最近では実施しない例が多い ${ }^{18)}$ 。 また, 酸化膜形成手段として陽極酸化も検討された例が ある(19).20)。

これらの表面処理と耐食性との関連については炉外腐 食試験および原子炉内での照射試験によって調べられて いる。高温高圧水蒸気中での炉外腐食試験の結果では, 化学研磨はあまり腐食に影響しないが, 機械研磨により 生じる表面加工層がノジュラ一腐食を抑制する効果が見 られている ${ }^{21), 22)}$ 。表面処理の異なるジルカロイー 2 を 実験用原子炉で照射試験した結果 ${ }^{19)}$ を図 8 に示すが, 表 面処理の違いによる腐食量の差は小さい。また, 機械研 


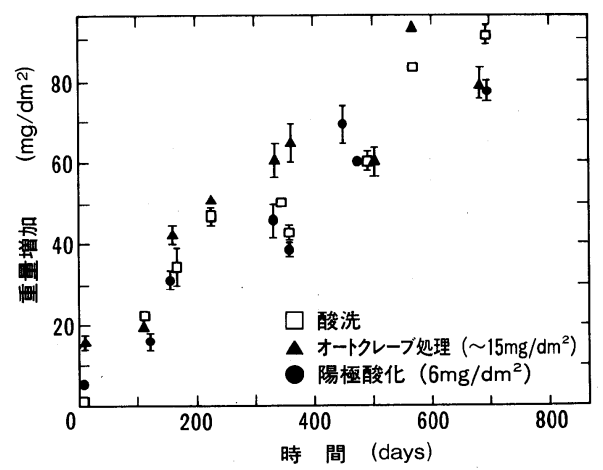

図 $8240^{\circ} \mathrm{C}$ 水中照射下のジルカロイの腐食に及ぼす表面処理の 影響 ${ }^{19}$

磨, 電解研磨, オートクレーブ処理でそれぞれ仕上げた 被覆管の原子炉内での腐食を比較した結果であ，各表面 処理の間で腐食量に系統だった差は見られず'12)，これら の表面処理方法が耐食性に及ぼす影響は小さいものと考 えられている。

ジルカロイ被覆管の外表面を他の材料で被覆する方法 については，前述の中性子吸収の点, Zr が脆い金属間 化合物を生成し易い点, あるいは密着性等の点からほと んど行われていない。但し, 被覆管内面については, 腐 食性核分裂生成物と応力との重畳作用による応力腐食割 れ対策として，純Zrを内張りしたZrライナおよび銅めっ き $(\mathrm{Cu}-\mathrm{Zr}$ 金属間化合物形成を防ぐため中間に酸化膜層 を設けている）した銅バリアが種々の試験に供されてお $り^{23)} ， \operatorname{Zr}$ ライナ被覆管は現在実用化されている。

\section{3 被覆管の耐食性改善}

被覆管材料は前述のとおり中性子吸収および強度・延 性の点から今後むZr基合金が主流と考えられ，熱処理， 合金組成の改良およびこれらの組み合わせによる耐食性 改善研究が進められている。

$\mathrm{Zr}$ は $862^{\circ} \mathrm{C}$ を境にして低温で安定な $\alpha$ （稠密六方格子） から $\beta$ (体心立方格子) へ変態する。ジルカロイの合金

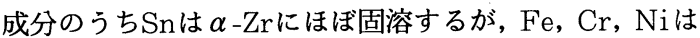
$\beta-Z r に は$ 固溶するが $\alpha-\operatorname{Zr}$ では固溶限が非常に低いため に大半が粒径 $1 \mu \mathrm{m}$ 以下の金属間化合物として析出する。 ジルカロイの耐食性は図 9 $^{11)}$ に示すように熱処理条件に よって変化し, 特に $\beta$ 相温度加ら急冷 ( $\beta$ 焼入れ) すると 耐食性が向上することが良く知られている。その効果は 図10 ${ }^{12)}$ に示すように急冷時の冷却速度に依存する。 $\beta$ 焼 入れ時には， $\beta$ 相温度で固溶した合金成分が泠却時に析 出するが，冷却速度が速い場合には析出物が微細に分散 するとと屯に一部はマトリックス中に過飽和に固溶す る。腐食機構への合金元素の寄与としては, 酸化膜中で の析出物を通した電子輸送 ${ }^{24)}{ }^{25)}$ あるいは合金元素と $\mathrm{Zr}$

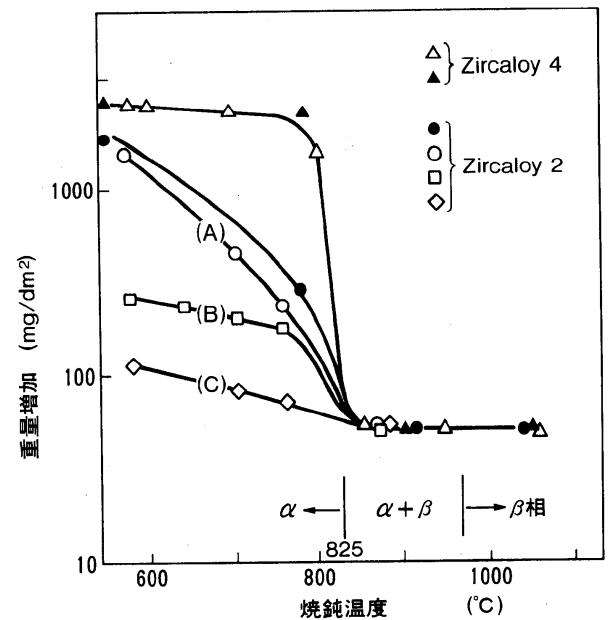

図 9 ジルカロイ -2 および- 4 の熱処理温度と腐食重量増加 の関係 ${ }^{11}$

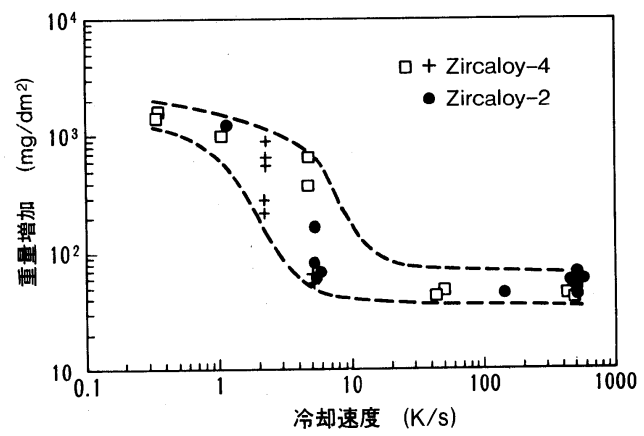

図10 $\beta$ 相で加熱後の冷却速度之水蒸気中腐食重量増加の関係 ${ }^{12)}$

との原子価の違いによる $\mathrm{ZrO}_{2}$ の定組成比からのずれ ${ }^{11,12)}$ などが挙げられており，これら合金成分の析出状態や微 量の固溶成分が大きく影響しているあのと考えられる。

一方，被覆管の製造効率という点では，製造工程の上 流側で $\beta$ 焼入れを行うのが有利であるが，その後の加工・ 熱処理工程でその効果が損なわれないようにする必要が ある。このため， $\beta$ 焼入れを施す時期とその後の熱処理 条件の最適化について種々検討されている。現在, 製造 工程の中間製品である素管の外表面のみに焼入れする方 法が実用化されており，レーザを利用した外表面焼入れ 方法も提案されている。

合金成分の改良という点では, ジルカロイの組成をよ り最適な值にしようとするあのや，Zr-Nb合金などが考 えられている。ジルカロイの組成は種々の試験結果に基 づいて安定した耐食性が得られる範囲として決定され ${ }^{6)}$, その後豊富な使用実績が得られているが, 各合金元素個々 の効果の程度を勘案して組成を最適化しようとする試み が行われている ${ }^{27)}$ 。 Zr-Nb 2 元合金は燃料被覆管（Zr$1 \% \mathrm{Nb})$ としてソ連で，重水炉の圧力管（Zr-2.5\% Nb） としてカナダでそれぞれ使用されているが，焼入れと時 
効処理が必要であり, 溶接部で耐食性が低下し易い。こ れらの改善のためにZr-Nb合金に Sn, Fe, Cr, Ni, M ○等を微量添加した合金が種々提案されている28),29)。核 燃料材料は原子炬内の苛酷な条件下で高度の信頼性が要 求されるため，その評価には照射による影響あ含めて十 分なデータの蓄積が必要である。これら合金についてあ 多くの試験結果が報告されているが, 今のところ実用化 するには至っていない。

\section{4.あとがき}

軽水炉は今後屯原子力発電の主流と考えられ，より一 層の技術の高度化が進められている。核燃料材料の挙動 には, 水の放射線分解, 材料の照射損傷といった原子炉 内固有の現象が影響しており，その評価には炉外試験に よる基礎的な研究に加えて長期間にわたる照射試験が不 可欠となっている。今後高燃焼度化を進める上で重要な テーマの一つである燃料棒外面腐食に関しても, その現 象解明と耐食性改善に向けて, 照射下での腐食環境およ び材料特性の両面から広範囲な研究開発が続けられてい る。これらの成果が原子力発電の信頼性と経済性の向上 につながってゆくあのと期待される。

(1988-8-12 受理)

\section{文 献}

1）三島良績, 大久保忠恒, 青木利昌, 二見常夫, 北村信行, 藤林 徹, 小泉成実, 野俣輝満, 津久井一茂, 永井将之, 松 島安義, 大内淳弘; 日本原子力学会誌, 29, 90 (1987)

2) Y. Irisa, T. Takada, H. Kudo, Y. Kondo, A. Nagano, H. Takahashi, T. Kodama, J. Yamaki, Y. Mishima, T. Okubo, M. Oishi and T. Aoki ; Proc. International Topical Mtg. on LWR Fuel Performance, Williamsburg, p. 102 (American Nuclear Society, 1988)

3）福田秀敬, 青木利昌; 原子力工業, 34 (6), 7 (1988)

4) D. Franklin, U. Wolff and D. O'Boyle ; Proc. International Topical Mtg. on LWR Fuel Performance, Williamsburg, p. 3 (American Nuclear Society, 1988)

5) Y. Mishima ; Proc. IAEA Specialists' Mtg. on Influence of Water Chemistry on Fuel Element Cladding Bhavior in Water Cooled Power Reactors, Reningrad, USS R (International Atomic Energy Agency, 1983)

6) S. Kass ; Corrosion of Zirconium Alloys, ASTM STP 368, p. 3 (American Society for Testing and Materials, 1964)

7) J. J. Kearns ; J. Nucl. Mater., 20, 292 (1967)

8) B. Cox ; Advances in Corrosion Science and Technology (Plenum Press, 1976)

9) E. Hillner ; Zirconium in the Nuclear Industry, ASTM STP 633, p. 211 (American Society for Testing and Materials, 1977)

10) A. W. Urquhart and D. A. Vermilyea ; J. Nucl Mater.,62,
111 (1976)

11) B. Cheng and R. B. Adamson; Zirconium in the Nuclear Industry, ASTM STP 939, p. 387 (American Society for Testing and Materials, 1987)

12) F. Garzarolli, H. Stehle, E. Steinberg and H. Weidinger ; Zirconium in the Nuclear Industry, ASTM STP 939, p. 417 (American Society for Testing and Materials, 1987)

13) H. Stehle, W. Kaden and R. Manzel ; Nucl. Eng. Des., 33, 155 (1975)

14) F. Garzarolli and H. Stehle ; Proc. IAEA International Symposium on Improvements in Water Reactor Fuel Technology, IAEA-SM-288/24 (International Atomic Energy Agency, 1986)

15) F. Garzarolli, R. Manzel and F. Wunderlich; Proc. IAE A Specialists' Mtg. on High Burnup in Power Reactor Fuel, Mol (International Atomic Energy Agency, 1981)

16) B. Cox ; J. Nucl. Mater., 28, 1 (1968)

17) R. Sumerling, A. Garlick, A. Stuttard, J. M. Hartog, F. W. Trowse and P. Sims ; Zirconium in the Nuclear Industry,ASTM STP 687, p. 107 (American Society for Testing and Materials, 1979)

18) K.S. Venkateswarlu and G. Venkateswaran ; Proc. Technical Committee Mtg. on External Cladding Corrosion in Water Reactors, Cadarashe (International Atomic Energy Agency, 1985)

19) L. Lunde and K. Videm ; Zirconium in the Nuclear Applications, ASTM STP 551, p. 514 (American Society for Testing and Materials, 1974)

20) A. Conte, A. Borello and A. Cabrini ; J. Appl. Electrochem., 6, 293 (1976)

21) K. Ogata, T. Motomiya and Y. Wakashima ; Nuclear Fuel Performance, p. 381 (British Nuclear Energy Society, 1985)

22) R. Kuwae, K. Sato, J. Kawashima and E. Higashinakagawa; J. Nucl. Mater., 23, 661 (1986)

23) K. Inoue, K. Suzuki, H. Maki, T. Yasuda, N. Oi, Y. Hayashi, Y. Wakashima, K. Ogata, S. Junkrans, G. Vesterlund, G. Lysell and G. Rönnberg ; Proc. ANS Topical Mtg. on Light Water Reactor Fuel Performance, Orland, p. 1-17 (American Nuclear Society, 1985)

24) A. W. Urquhart, D. A. Vermilyea and W. A. Rocco ; J. Electrochem. Soc., 125, 199 (1978)

25) R. Kuwae, K. Sato, E. Higashinakagawa,J. Kawashima and S. Nakamura ; J. Nucl. Mater., 119, 229 (1983)

26）稲垣正寿, 赤堀公彦, 神保龍太郎, 牧 英夫; 日本原子力 学会誌, 27, 743 (1985)

27) H. G. Wiedinger, F. Garzarolli, C. M. Eucken and E. F. Baroch ; Zirconium in the Nuclear Industry, ASTM STP 939, p. 364 (American Society for Testing and Materials, 1987)

28) C. Tyzack, P. Hurst, G. F. Slattery, F. W. Trowse, A. Garlick, R. Sumerling, A. Stuttard, K. Videm, L. Lunde, M. Warren, E. Tolksdorf, P. Tarkpea and J. Forsten ; $J$. Nucl. Mater., 66, 163 (1977)

29) L. Castaldelli, C. Fizzotti and L. Lunde ; Zirconium in the Nuclear Industry, ASTM STP 754, p. 105 (American Society for Testing and Materials, 1982) 